\title{
Pendampingan Kelompok Tani di Kabupaten Pamekasan untuk Pengembangan Entrepeneur Agribisnis Jagung Madura
}

\author{
Isdiana Suprapti, Aminah Happy \\ Program Studi Agribisnis Fakultas Pertanian \\ Universitas Trunojoyo Madura \\ E-mail : ana.utm@gmail.com \\ http://dx.doi.org/10.21107/pgd.v4i2.4931
}

\begin{abstract}
Abstrak
Madura sebagai salah satu sentra penghasil jagung, memberikan suatu peluang yang cukup besar bagi para petani jagung untuk meningkatkan pengetahuan dan ketrampilan akan komoditas jagung. Kelompok tani yang ada saat ini, hanya mampu mengembangkan kemampuan budidaya petani tetapi belum mampu mengembangkan kemampuan kewirausahaan petani dibidang agribisnis atau belum mampu melahirkan entrepreneur agribisnis. Penerima manfaat dalam program ini adalah kelompok tani Kuntum Mekar Desa Sopa'ah dan kelompok tani Kuntum Muda Desa Durbuk, kecamatan Pademawu. Program pengabdian kepada masyarakat ini dimaksudkan untuk memberikan alternatif ilmu pengetahuan dan teknologi yang berguna bagi peningkatan kapasitas kelembagaan kelompok tani dalam menggali sumber-sumber pendapatan mandiri dan sebagai alternatif ketrampilan praktis untuk menumbuhkan jiwa kewirausahaan pada kelompok tani. Kegiatan ini membantu petani untuk mengembangkan jiwa entrepreneur agribisnis komoditas jagung, sebagai bentuk pengembangan ketrampilan dan pengetahuan petani akan komoditas jagung. Beberapa kegiatan pelatihan berupa : (a) pelatihan manajemen agribisnis jagung, (b) sekolah lapang yang terdiri dari pemberian materi teknik budidaya Legowo Jagung, pengolahan lahan, pemberian pupuk dasar dan pembuatan pupuk organic, penanaman dan pembuatan farm record, pemupukan dan pengamatan hama; (c) pelatihan diversifikasi olahan jagung berupa susu jagung dan sari jagung instan.
\end{abstract}

Kata kunci: Entrepeneur, agribisnis, jagung, kelompok tani, pengabdian masyarakat

\section{PENDAHULUAN}

Kebijakan pengembangan jagung hibrida dan komposit oleh pemerintah mempengaruhi petani jagung Madura. Pulau Madura yang merupakan salah satusentra produsen jagung (luas areal tanam 400 ribu hektar atau terluas di Jawa Timur),juga sudah ditanami jagung hibrida dan komposit. Luas areal tanam jagung hibrida diMadura mengalami peningkatan setiap tahun. Pada tahun 2011, luas areal tanamagung hibrida di Kabupaten Sumenep mencapai 14,37 ribu Ha atau 9,6\% dari luasareal tanam jagung. Luas tersebut meningkat $29 \%$ dibanding pada tahun 2010.Masuknya jagung hibrida tersebut mempengaruhi produktifitas jagung di Madura yangawalnya hanya sekitar 1,4 ton per hektar (Roesmarkam dkk., 2006) meningkat menjadi4,2 ton per Ha. Produktifitas tersebut jauh lebih rendah dari jagung hibrida (8-10 ton/Ha), jagung komposit (5-6 ton/Ha), tetapi sudah setara dengan rata-rata produktifitas jagung tingkat nasional yaitu 4,2 ton/Ha (Zakaria, 2011). Produktivitasyang rendah disebabkan oleh lahan yang kurang subur, curah hujan yang rendah,dan penggunaan benih lokal yang tanpa seleksi (Roesmarkam dan Sa'adah, 2009).
Pengembangan jagung hibrida dan komposit tidak banyak mempengaruhi keputusan petani jagung madura dalam menanam jagung lokal. Petani jagung Madura masih lebih memilih menanam jagung lokal. Sugiarti et.al (2009) menyatakan bahwa petani Madura menolak komoditas jagung varietas baru dan memutuskan untuk menanam jagung lokal. Petani madura masih menganggap lebih baik menanam jagung lokal, meskipun hasil penelitian Nurmansyah (2011) menyatakan bahwa ustan jagung lokal madura lebih rendah dibandingkan jagung hibrida. Pendapatan usahatani jagung lokal sebesar Rp 2.019.491,15/ha, sedangkan pendapatan jagung hibrida sebesar Rp 5.349.747,54/ha. Menurut Suprapti (2013), petani jagung madura memiliki keefisienan secara alokatif dalam usahatani jagung madura artinya tingkat kesediaan petani terhadap pembiayaan usahatani jagung madura tinggi. Hal ini dikarenakan berbagai faktor seperti : (i) sebagai bahan pangan, (ii) sebagai benih untuk musim tanam berikutnya, (iii) model penyimpanan jagung yang cukup lama sehingga tidak memerlukan biaya simpan yang tinggi, (iv) biaya produksi yang cukup rendah dibandingkan 
biaya produksi jagung hibrida, (v) adanya ceruk pasar yang membuatharga jagung madura relatif lebih tinggi dibandingkan jagung hibrida. Selain itu petanimadura juga memiliki keberanian dalam melakukan manajemen risiko produksi baik risiko ex-ante, interaktif maupun ex-post.

Berdasarkan penelitian ini jagung madura memiliki potensi yang cukup signifikan untuk ditingkatkan, dengan berbagai alasan yaitu : (i) loyalitas petani jagung madura yang sangat tinggi, bisa dijadikan sebagai dasar untuk pembinaan peningkatan jumlah produksi jagung (budidaya), (ii) ketersediaan produksi jagung cukup besar tetapi belum ada nilai tambah, (iii) belum jelasnya pemasaran jagung madura secara keseluruhan, sehingga bisa di buat strategi pemasaran yang baik, (iv) kebijakan pemerintah daerah yang setengah hati untuk membantu petani jagung madura.

Pengembangan usaha jagung sebagai salah satu komoditas pangan, sangat membutuhkan petani sebagai pelaku produsen jagung. Tetapi keberadaan petani jagung atau petani secara umum sampai saat ini masih termarginalkan. Data Badan Pusat Statistik (BPS) menunjukkan, nilai tukar petani terus merosot. Pada tahun 1976, nilai tukar petani 113, pada 1979 dan 1989 bahkan mencapai angka tertinggi, yakni 117. Namun, pada 1993 merosot menjadi 95 dan pada tahun 2009 nilai tukar petani bulanan tertinggi hanya 101 (Wiranthi, 2010). Salah satu penyebab merosotnya nilai tukar petani karena fungsi kelembagaan pertanian masih lemah dan belum mampu memperbaiki citra dan perannya di masyarakat petani. Keberadan kelompok tani sebagai salah satu lembaga petani belum mampu mengembangkan sumberdaya manusia petani ke arah yang lebih baik. Kelompok tani hanya mampu mengembangkan kemampuan budidaya petani, tapi belum mampu mengembangkan kemampuan kewirausahaan petani dibidang agribisnis atau belum mampu melahirkan entrepreneur agribisnis.

Dengan demikian entrepreneur agribisnis yang kuat perlu dikembangkan dalam jumlah banyak karena beberapa alasan mendasar yaitu (i) agribisnis tropis dalam proses produksi, kandungan lokalnya banyak bersumber dari kekayaan domestik, (ii) tenaga kerja yang dibutuhkan juga banyak dan cocok sesuai dengan berbagai strata jenis usaha, (iii) pasar produk barang dan jasa agribisnis akan mudah dipasarkan karena jumlah penduduk Indonesia hampir 250 juta orang.
Selain itu penduduk Indonesia banyak menganggur (lebih 10 juta menganggur penuh, 10 juta setengah menggangur dan setiap tahun ada 2,5 juta perlu pekerjaan). Orang miskin dan penganggur selalu perlu pangan dan pekerjaan. Utang pemerintah dan swasta mencapai lebih dari 3000 trilyun. Kerusakan lingkungan (hutan rusak, banjir, pencemaran air dan lahan) terjadi di banyak tempat. Pengembangan entrepreneur agribisnis dalam sistem dan usaha agribisnis yang terarah dan terkendali dapat menghasilkan sandang-pangan-papan, menciptakan lapangan kerja, mengurangi kerusakan lingkungan dan tidak menimbulkan utang baru yang kurang produktif. (Pambudy, 2010).

Kelompok Tani Kuntum Mekar dan Kuntum Muda merupakan Kelompok Tani terdapat di Kabupaten Pamekasan. Kelompok tani Kuntum Muda terletak di Desa Durbuk Kecamatan Pademawu, sedangkan Kuntum Mekar terletak di Desa Sopa'ah Kecamatan Pademawu. Desa Sopa'ah dan Desa Durbuk merupakan Desa yang terletak di Pinggir Kota Pamekasan, berjarak sekitar $5 \mathrm{~km}$ sebelah tenggara dari kota Pamekasan. Kelompok tani "Kuntum Mekar" yang diketuai oleh Abu Yamin memiliki anggota 40. Rata-rata usia tenaga kerja tetap antara 30 sampai dengan 60 tahun dengan tingkat pendidikan tamat SD, SMP dan SMA yang sebagian berasal darikeluarga dan masyarakat sekitar lokasi tersebut. Sedangkan kelompok Tani "KuntumMekar" diketuai oleh Sis Suharyono, memiliki anggota 30 orang. Ratarata usia anggota kelompok tani antara 30-60 tahun dengan tingkat pendidikan SMP dan SMA.Semua anggota kelompok tani tersebut adalah laki-laki. Perempuan yang merupakan istri atau anak dari tidak tergabung dalam kelompok tani, tetapi dalam kelompok pengajian. Perempuan di desa tersebut sebagian memiliki usaha pengolahan makanan basah dan makanan kering, dan minuman. Makanan tersebut dijual secara langsung atau dimasukkan ke warung dan toko-toko besar di kota Pamekasan. Salah satu olahan yang khas dikerjakan oleh ibu-ibu di Desa Durbuk yaitu sari / susu kedelai.

Berdasarkan hasil wawancara dengan pengurus kelompok, sebagian besar tanaman yang dibudidayakan kelompok tani ini adalah Padi dan Tembakau. Tanaman jagung ditanam dua kali musim yaitu diantara musim tanam padi dan tembakau dan sebaliknya. Rata-rata petani anggota kelompok tani Kuntum Muda dan Kuntum Mekar memiliki luas lahan antara 0,1- 
0,5 Ha. Hasil tani jagung sekitar sebesar $5-10$ sak jagung tiap petak sawah atau rata-rata sekitar 1 ton /ha. Hasil ini sebagian besar disimpan untuk kemudian dijual dalam bentuk pipilan jika ada kebutuhan rumah tangga.

Sejak gagalnya usaha tani tembakau pada beberapa tahun terakhir, banyak petani kebingungan mencari tanaman alternatif. Meskipun sebagian petani masih bertahan bertani tembakau, tetapi sebagian petani mengalihkan usaha budidaya tembakau ke usaha tani jagung dengan alasan untuk simpanan kebutuhan keluarga. Selain itu perawatan jagung yang mudah dan murah. Bagi petani di kedua kelompok tani tersebut, jagung yang tumbuh tanpa dirawat juga akan tetap bisa berbiji, artinya petani jarang melakukan perawatan intensif terhadap jagung madura yang mereka tanam.

Hasil analisis situasi dan kenyataan di lapangan serta berdasarkan diskusi dengan anggota kelompok tani "Kuntum Muda" dan "Kuntum Mekar" berkaitan dengan agribisnis jagung madura, dapat diidentifikasi beberapa permasalahan antara lain:

1. Lemahnya manajemen sumberdaya manusia. Hal ini dibuktikan dengan struktur organisasi yang terdapat pada kedua kelompok tani tersebut masih sederhana, yaitu hanya terdiri atas ketua, sekretaris dan bendahara dan tidak memiliki divisi-divisi. Akibatnya semua tugas dilaksanakan oleh pengurus inti. Tingkat pendidikan sebagian anggota kelompok yang masih rendah menyebabkan pola pikir (mindset) petani selama ini hanya melakukan usaha taninya secara subsisten saja dan belum mempunyai tujuan komersial.

2. Rendahnya pengetahuan petani tentang inovasi budidaya tanaman. Hal ini dibuktikan dengan ketergantungan petani terhadap usaha tani tembakau yang sangat besar. Petani kurang berani mencoba untuk mengembangkan budidaya tanaman alternatif selain tembakau. Tanaman jagung madura yang dibudidayakan, hanya menggunakan sistem tradisional dan dengan peralatan seadanya. Selain ketergantungan terhadap tanaman tembakau, petani juga petani cukup pada pupuk pemerintah, serta hasil yang dijual masih berupa bahan mentah (pipilan). Program PUAP (Program Usaha Agribisnis Pedesaan) yang digulirkan pemerintah dengan harapan petani mampu mengembangkan usaha taninya, lebih banyak digunakan untuk kegiatan on farm saja dan lebih besar untuk pembiayaan budidaya tembakau. Petani tidak memiliki usaha sampingan untuk meningkatkan nilai tambah produk melalui pengolahan. Akibatnya dana PUAP, banyak mandeg di tingkat petani karena kegagalan panen. Petani juga kurang bisa menjual produk yang dihasilkan dan belum mengetahui syarat-syarat penerimaan pasar terhadap produk mereka.

3. Rendahnya pengetahuan petani tentang peran dan fungsi kelembagaan pertanian. Kelompok tani bagi anggota kedua kelompok, lebih sebagai lembaga simpan pinjam. Kelompok tani belum bisa menjalankan fungsi-fungsi pengelolaan usaha tani secara terpadu diantara anggota kelompok mereka. Petani di kedua desa, baik yang tergabung atau tidak dalam kelompok tani cenderung melakukan usaha taninya secara individual. Petani belum memanfaatkan keberadaan kelompok tani sebagai lembaga yang dapat meningkatkan pengetahuan dan keterampilannya dalam usaha tani secara luas.

4. Lemahnya daya inovasi teknologi pengolahan pangan. Anggota kedua kelompok tani belum mencoba untuk mengolah hasil taninya, terutama jagung padahal sebagaian istri anggota kelompok memiliki usaha pengolahan makanan.

Permasalahan yang dihadapi oleh mitra diantaranya kurangnya pengetahuan petani jagung dalam mewujudkan entrepeneur agribisnis (dari segi manajemen on farm, off farm, pemasaran). Disamping itu, budidaya on farm yang selama ini dipakai oleh mitra masih tradisional dan hasil panen dijual tanpa ada nilai tambah. Dari sisi pemasaran belum dilakukan inovasi pemasaran yang strategis. Keterbatasan manajemen mitra dan peralatan produksi berdampak pada kurang berjalannya kegiatan pembelajaran agribisnis dan kewirausahaan. Menurut Cahyono dan Adi (2003) keterbatasan teknologi pengolahan dan modal yang dimiliki oleh pengusaha kecil mengakibatkan daya saing agroindustri menjadi rendah. Pengusul (di bawah institusi LPPM Universitas Trunojoyo Madura) diharapkan dapat menjadi agent of change untuk transfer ilmu pengetahuan dan teknologi kepada mitra. Perguruan Tinggi melalui pengusul diharapkan dapat memberikan alternatif pemecahan masalah dengan menerapkan ilmu pengetahuan, teknologi (IPTEK) yang telah diteliti dan diterapkan di Universitas Trunojoyo Madura. 


\section{METODE}

Program pengabdian masyarakat melalui pendampingan Kelompok Tani ini memiliki target luaran berupa teknologi budidaya tanaman jagung, pengolahan (diversifikasi olahan jagung) serta pembelajaran agribisnis dan kewirausahaan yang diimplementasikan dalam bentuk :

1. Pelatihan Manajemen Agribisnis, yang dimaksudkan untuk peningkatan pengetahuan dan kemampuan kelompok tani tentang manajemen sumberdaya manusia, manajemen usaha agribisnis, sehingga peranan kelompok tani yaitu sebagai unit produksi, unit pengolahan dan pemasaran serta sebagai pengambil keputusan dalam usahatani dan usaha lainnya dapat terwujud.

2. Sekolah Lapang, yang dimaksudkan untukpeningkatan kemampuan petani dalam mengusahakan teknik budidaya jagung. Teknik budidaya ini dimaksudkan untuk meningkatkan produktivitas jagung, membuat pupuk organic yang bisa mengurangi biaya produksi. Serta meningkatkan kemandirian kelompok tani dengan mengembangkan jiwa kewirausahaan (entrepreneurship) dan pengelolaan usahatani secara komersial, berkelanjutan dan ramah lingkungan.

3. Pelatihan Diversifikasi olahan jagung, yang dimaksudkan untuk menghasilkan produk olahan jagung (sari/susu jagung) yang bernilai ekonomis.

Dengan metode tersebut yang diharapkan dapat memberikan solusi kepada kedua mitra, yaitu :

1. Mitra memiliki pengetahuan tentang metode budidaya jagung jajar legowo, sehingga produksi jagung dapat ditingkatkan.

2. Produk jagung yang dihasilkan dapat diolah menjadi susu jagung dan sari jagung, sehingga pendapatan mitra bisa ditingkatkan.

3. Ketrampilan manajemen, baik manajemen sumberdaya manusia, produksi dan pemasaran yang dimiliki mitra lebih baik.

Rencana kegiatan entrepreneur agribisnis, dari pelatihan manajemen agribisnis, teknik budidaya Legowo jagung, pelatihan diversifikasi olahan jagung, dan pemecahan permasalahan mitra adalah sebagai berikut :

1. Sosialisasi program kegiatan kepada kedua kelompok tani.

2. Pelatihan manajemen agribisnis.

3. Sekolah lapang 1, berupa pemberian materi teknik budidaya legowo jagung.
4. Penyiapan sekolah lapang 2, berupa pengolahan lahan, pemberian pupuk dasar dan pembuatan pupuk organik.

5. Penyiapan sekolah lapang 3, berupa penanaman tahap 1 dan pembuatan farm record.

6. Penyiapan sekolah lapang 4, berupa pemupukan 1 dan pengamatan hama.

7. Penyiapan pelatihan diversifikasi olahan jagung.

8. Penyiapan sekolah lapang 5, berupa penanaman tahap 2 dan pembuatan pakan ternak fermentasi.

9. Penyiapan sekolah lapang 6, berupa pemanenan dan penanaman tahap 3 .

\section{HASIL DAN PEMBAHASAN}

Hasil survey lapang dan potensi mitra IbM menunjukkan bahwa terdapat perbedaan karakteristik mitra yaitu :

a. UKM Kuntum Mekar Desa Sopa'ah

- Memiliki struktur organisasi yang sederhana, hal ini disesuaikan dengan kebutuhan kelompok tani.

- Berdiri sejak tahun 2004, dengan jumlah anggota 20 petani, namun yang aktif sampai saat ini sekitar 10 petani.

- Pertemuan rutin, setiap tanggal 10/bulannya yang dihadiri oleh semua anggota.

b. UKM Kuntum Muda Desa Burbuk

- Memiliki struktur organisasi yang lebih lengkap

- Berdiri sejak tahun 2004, di desa Durbuk dengan jumlah anggota 40 petani, namun yang aktif dalam kegiatan hanya 10 petani.

- Pertemuan rutin, setiap tanggal 15/bulannya yang dihadiri oleh semua anggota.

Untuk memberikan solusi atas permasalahan mitra, maka kegiatan IbM dibagi dalam beberapa tahap yaitu (i) Pelatihan manajemen agribisnis, (ii) sekolah lapang, (iii) pelatihan diversifikasi pengolahan jagung.

\section{Pelatihan Manajemen Agribisnis}

Pelatihan ini dimaksudkan untuk memberikan pemahaman kepada petani tentang ruang lingkup agribisnis. Jika dahulu pertanian diartikan secara sangat sempit, semata-mata hanya melihat subsistem produksi atau usahataninya saja, maka 
saat ini pertanian diartikan secara lebih luas, dari hulu, on-farm hingga hilir (usaha agribisnis). atau image dari produknya itu sendiri. Untuk strategi ini biasanya diikuti dengan biaya yang
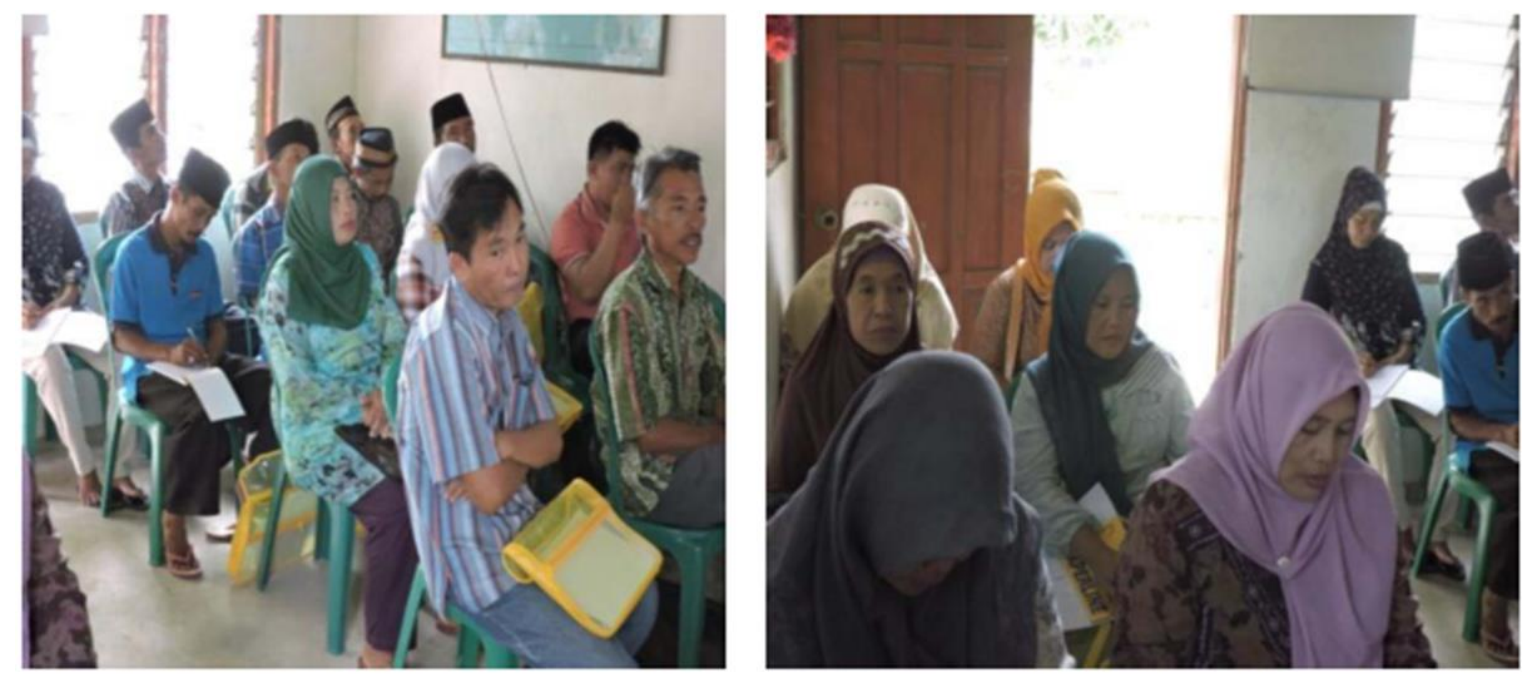

Gambar 1. Dokumentasi Pelatihan Manajemen Agribisnis

Setelah memahami tentang Ruang Lingkup ini, maka petani diberikan pemahaman tentang karakteristik umum yang dapat dijadikan dasar dalam pengembangan produk pertanian seperti : (1) Umur tanam hingga produksi, (2) Lama konsumsi dari produk pertanian tersebut (umur simpan), (3) Variabilitas bahan untuk diolah dari satu produk ke produk yang lain, (4) Cara penanganan pasca panen, penyimpanan dan penyajian, (5) Kesesuaian dengan standar yang ditetapkan, (6) Penampakan produk dalam rangka menarik minat konsumen, (7) Aspek lingkungan pemasaran.

Hal lain yang juga perlu diperhatikan dalam kaitannya dengan aspek pemasaran produk adalah strategi pemasaran yang bagaimana yang akan dipilih oleh perusahaan dalam kaitannya dengan produk yang dibuat. Porter (1985) mengemukakan bahwa pada dasarnya ada 3 strategi penting untuk mendapatkan kesuksesan dalam bidang pemasaran produk, yaitu:(1) Keunggulan dalam biaya / ongkos. Pemasaran produk dengan mengandalkan keunggulan dalam biaya, misalnya menjual produk dengan harga yang murah namun dengan kualitas yang baik. Hal ini bisa dilakukan karena perusahaan mampu menghemat biaya produksi dalam proses produksi, baik pada pemilihan bahan baku, proses, kemasan maupun biaya untuk tenaga kerja; (2) Keunggulan karena adanya ciri pembeda atau keunikan dari produk yang dibuat (diferensiasi). Strategi ini menekankan pada aspek keunikan pada produk yang dipasarkan, baik penekanan pada merk, bentuk, logo, kualitas tinggi, (3) Keunggulan karena memfokuskan pada target atau segmen pasar tertentu. Strategi ini mengandalkan pada suatu fokus tertentu, misalnya hanya mengkhususkan pada segmen pasar "remaja" atau orang tua saja.

\section{Sekolah Lapang}

Kegiatan sekolah lapang terbagi dalam beberapa tahapan yaitu :

Sekolah Lapang 1 : Pemberian Materi Teknik Budidaya Legowo Jagung

Kegiatan ini bertujuan untuk memaparkan manfaat teknik budidaya legowo jagung, yang sudah pernah dilakukan penelitian sejak tahun 2010-2013. Teknik penanaman ini, dimaksudkan untuk meningkatkan tingkat produktivitas dari jagung. Proses penanaman jagung 6 kali panen setelah penanaman padi dalam setahun merupakan salah satu cara meningkatkan daya guna lahan, frekuensi penanaman dan produksi jagung. Pola tanam proses ini menggabungkan penanaman jagung Madura (krajekan) yang berumur pendek (55-60 hari) dengan jagung hibrida berumur sedang (75- 80 hari) dengan potensi di produksi 6 ton lebih.

Sekolah Lapang 2: Pengolahan Lahan, Pemberian Pupuk Dasar dan Pembuatan Pupuk Organik

Kegiatan ini merupakan praktek langsung di sawah tentang teknik budidaya legowo jagung. Pada sekolah lapang kedua ini peserta dikenalkan tentang teknik pembuatan bedengan dan teknik pemupukan dasar. 

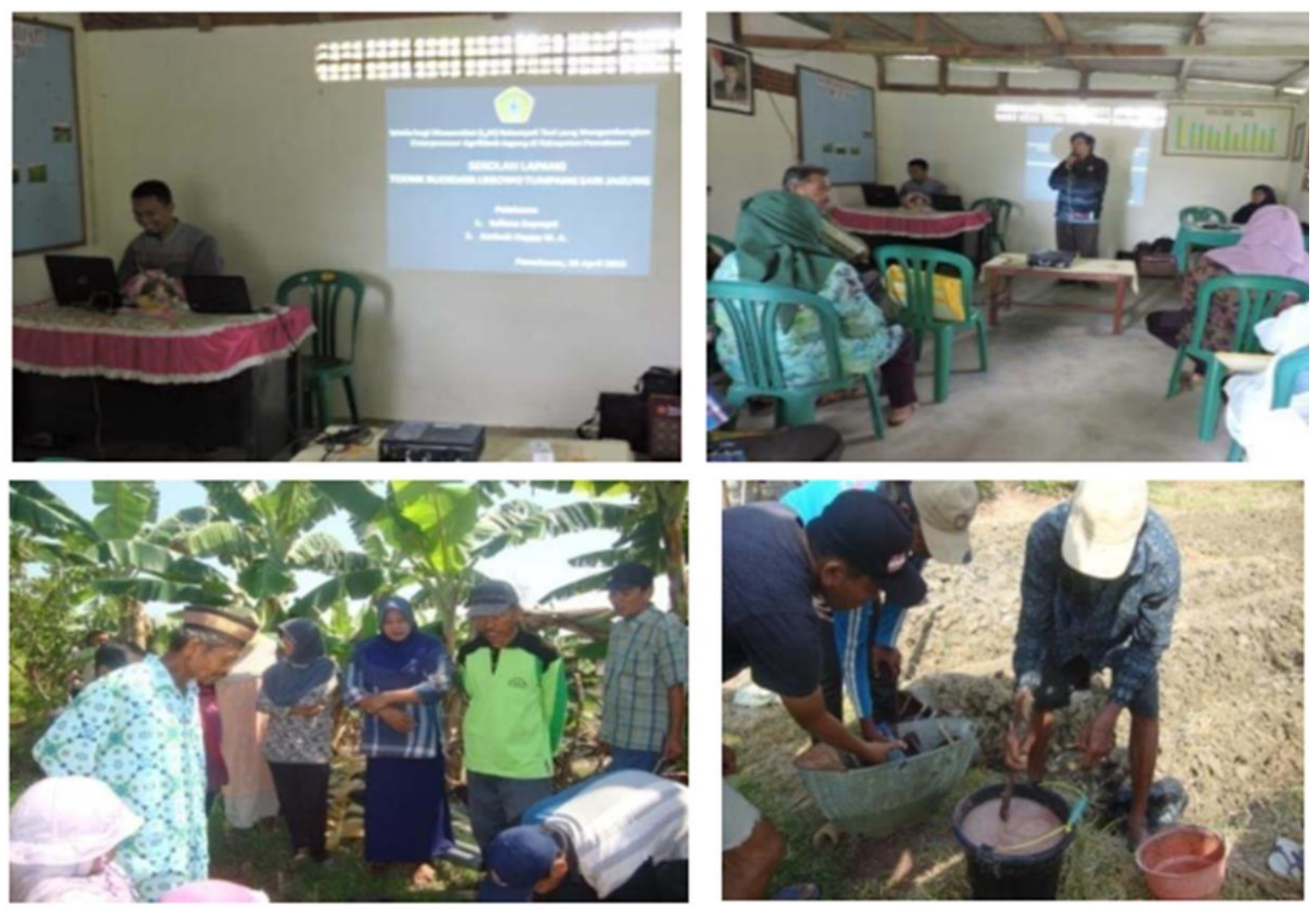

Gambar 2. Dokumentasi Pengolahan Lahan

Lebar bedengan yang dibuat adalah 1 meter. Pupuk yang digunakan adalah Urea, TSP dan $\mathrm{KCl}$. Peserta juga dikenalkan dengan pembuatan pupuk organik cair dengan menggunakan bahanbahan sisa kegiatan rumah tangga, kotoran sapi dan telur

ayam. Pupuk organik cair yang dapat diaplikasikan pada jagung yang berumur satu bulan baik melalui akar maupun melalui daun.

\section{Sekolah Lapang 3 : Penanaman Tahap 1 dan Pembuatan Farm Record}

Pada pertemuan ketiga ini, pelatihan dilakukan di dalam ruang dan di lapang (sawah). Pelatihan pertama berupa pembuatan farm record (rekam tani). Peserta belajar mengisi tabel yang berisi keterangan kegiatan budidaya jagung dari olah lahan sampai panen meliputi waktu, jumlah tenaga kerja dan biaya-biaya yang dikeluarkan. Teknik penanaman jagung yang dikenalkan sama dengan teknik penanaman pada umumnya. Jarak tanam antara jagung adalah $20 \times 80 \mathrm{~cm}$ yang masing-masing lubang diisi dengan satu biji jagung.

Sekolah Lapang 4: Pemupukan dan Pengamaatan Hama
Sekolah lapang keempat dilakukan di sawah. Peserta dikenalkan dengan dua teknik pemupukan. Teknik pertama pupuk yaitu pupuk dilarutkan dalam air sebelumdisiram ke tanaman, teknik kedua adalah pupuk langsung diletakkan $10 \mathrm{~cm}$ daritanaman. Pupuk yang digunakan adalah pupuk Urea dan pupuk organik yang telahdibuat pada pertemuan sebelumnya. Peserta juga dikenalkan dengan ciri jagungyang terkena hama dan penyakit. Ciri jagung yang terserang hama yaitu daunnyaterdapat bekas luka bekas gigitan ulat atau serangga. Penyakit pada jagungditandai dengan bercak kuning pada daun atau daun memutih. Pengendalian hama dan penyakit dilakukan dengan penyemprotan pestisida.

\section{Sekolah Lapang 5 : Penanaman Tahap 2 dan \\ Pembuatan Makanan Ternak Fermentasi}

Sekolah lapang 5 dilakukan di sawah. Waktu pelaksanaan 60 hari setelah penanaman tahap 1 . Pada penanaman tahap 2, biji jagung ditanam 15 $\mathrm{cm}$ sebelah dalam tanaman jagung tahap 1 . Sebelum ditanam, dilakukan pemangkasan terhadap daun tanaman jagung yang ditanam tahap 1. Daun yang dipangkas adalah semua daun dibawah daun tongkol. 


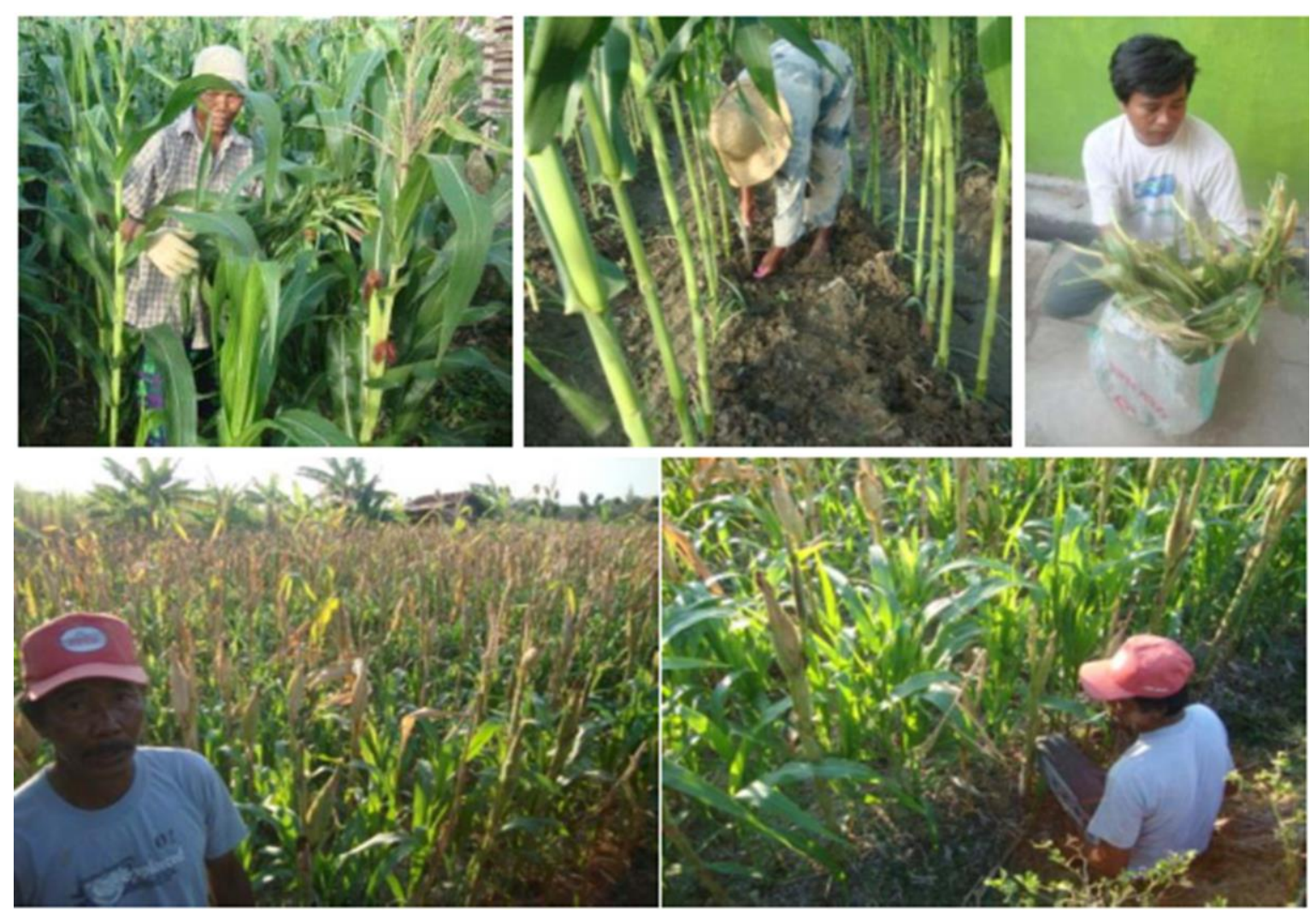

Gambar 3. Dokumentasi Penanaman Jagung dan Pembuatan Makanan Ternak

Sekolah Lapang 6: Panen dan Penanaman Tahap 3

Kegiatan sekolah lapang 6 adalah panen jagung. Waktu pelaksanaan 90 hari setelah penanaman tahap 1. Pada penanaman tahap 3, tanaman jagung yang siap panen diambil tongkol dan dicabut tanamannya. Batang jagung hibrida hasil panen ditaruh di antara guludan, kemudian ditimbun dengan tanah yang diambilkan pada tengah-tengah guludan. Selanjutnya saat umur tanaman jagung krajekan berumur 20 hari tanaman jagung MDR-1 (1) ditanam lagi di antara bekas tanaman jagung pertama ditanam, sehingga jarak tanam menjadi $80 \times 20 \mathrm{~cm}$.

\section{Pelatihan Diversifikasi Olahan Jagung}

Pelatihan ini di tujukan untuk memberikan ketrampilan lain dalam mengolah hasil jagung petani. Harapannya, dengan ketrampilan dan pengetahuan akan diversifikasi olahan jagung petani memiliki usaha yang bisa dikembangkan untuk rumah tangga atau dalam usaha kelompok tani. Kegiatan ini diawali dengan memberikan pengetahuan akan manfaat jagung Kemudian petani di ajari bagaimana mengolah jagung menjadi susu jagung dan sari jagung.
Berdasarkan berbagai sumber, manfaat jagung adalah :

- Melancarkan pencernaan. Jagung kaya akan serat yang membantu proses pencernaan.

- Baik bagi ibu hamil. Jagung kaya akan asam folat, nutrisi yang diperlukan untuk menurunkan risiko bayi lahir cacat.

- Menyehatkan mata. Jagung mengandung carotenoid yang menurunkan risiko kerusakan pada mata di usia senja.

- Menyehatkan jantung. Carotenoid pada jagung berperan dalam menurunkan risiko penggumpalan arteri.

- Kaya kalori dan vitamin. Jagung kaya akan vitamin B kompleks yang menjaga kesehatan saraf. Kaya mineral magnesium, mangan, zat besi, tembaga, seng, dan selenium.

- Mencegah anemia mengandung vitamin B12, asam folat, dan zat besi.

- Mengontrol diabetes. Ada senyawa tertentu dalam jagung yang mampu menurunkan risiko serangan penyakit ini.

- Melawan kanker. Jagung kaya akan antioksidan yang ampuh melawan beberapa jenis kanker.

- Menyehatkan kulit. Minyak jagung memang punya kemampuan dalam menyehatkan kulit secara alami. 


\section{KESIMPULAN}

Mitra petani dalam program kegiatan pengabdian masyarakat ini telah melakukan kegiatan entrepeneurship agribisnis jagung dari pengenalan manajemen agribisnis, sekolah lapang mengenai budidaya jagung dan pemanfaatan produk sekitar untuk mensiasati besarnya biaya penanaman berupa pupuk, serta pengolahan jagung menjadi produk yang memiliki nilai tambah dan bernilai jual. Implementasi teknologi budidaya jagung Jajar legowo dan pengolahan produk jagung menjadi susu jagung dan sari jagung yang diterapkan pada mitra petani dapat meningkatkan produksi jagung dan memberikan pendapatan tambahan.

Namun ada kekurangan dalam program ini, yaitu belum adanya analisis kelayakan budidaya jagung dengan metode jajar legowo dan nilai tambah dari olahan jagung serta mitra masih memerlukan pendampingan lebih lanjut, terutama dari sisi manajemen usaha. Beberapa masukan untuk keberlanjutan program pengabdian masyarakat ini adalah :

1. Guna meningkatkan pendapatan kemampuan manajemen mitra dalam mengelola usaha, perlu pembinaan baik dari perguruan tinggi maupun instansi terkait di wilayah Kabupaten Pamekasan.

2. Produk yang mampu dijual secara komersial oleh mitra selama program IbM adalah susu dan sari jagung, untuk itu kedepannya perlu dilakukan difersifikasi olahan jagung lainnya seperti tortila.

3. Unit usaha olahan jagung yang dimiliki oleh mitra belum memiliki ijin usaha, untuk itu kedepan diperlukan pendampingan dalam pengurusan izin usaha.

\section{DAFTAR PUSTAKA}

Biro Pusat Statistika. 2017. http:// bps.go.id

Pambudy, R. 2010. Melalui Kepemimpinan Entrepreneur Agribisnis. Makalah. Disampaikan pada Simposium Internasional PPI Dunia.

Roesmarkam, S., Arifin, F \& Sa`adah, S.Z. 2006. Usulan Pemutihan Varietas Lokal Jagung Madura Manding, Talango dan Gulukguluk. Balai Pengkajian Teknologi Pertanian Jawa Timur.

Sugiarti, T \& Hayati, M. 2009. Persepsi Petani Madura dalam Menolak Komoditas Jagung Varietas Baru. Jurnal Embryo. Vol 13 No 2.

Suprapti, I. 2013. Model Manajemen Risiko Petani Jagung Madura dalam Mempertahankan Keberadaan Jagung Lokal. Paper (tidak dipublikasikan). 